\title{
СТАТЬИ
}

UDC 347.44

\section{The principle of good faith and fair dealing in English contract law}

\author{
Jan Halberda
}

For citation: Halberda, Jan. 2020. The principle of good faith and fair dealing in English contract law. Pravovedenie 64 (3): 312-325. https://doi.org/10.21638/spbu25.2020.301

Given that continental civil law scholarship applies the concept of good faith in either a subjective (honesty in fact) or objective sense (good faith and fair dealing), the present article focuses on the latter one. The traditional view in England and Wales discards the recognition of a general principle of good faith and fair dealing in English law. English courts have adopted a piecemeal solutions approach (as shown by the judicial decisions issued in Interfoto Picture Library (1987) and Walford v. Miles (1992)). Meanwhile, the principle in question, along with the concept of the freedom of contract, is one of the most important principles of the continental civil law tradition (cf. art. 1104 of the French Civil Code, § 157, § 242 of the German Bürgerliches Gesetzbuch, art. 2 (1) of the Swiss Zivilgesetzbuch, art. 6:2 Burgerlijk Wetboek, art. 5 of the Polish Civil Code, art. 2 (1) Common European Sales Law, art. 1:201 Principles of European Contract Law, art. III1:103 Draft Common Frame of Reference). The current work analyzes recent English case law (in particular Yam Seng (2013)), which seems to acknowledge the principle of good faith and fair dealing while rejecting the traditional view mentioned above. The comparative approach - references to American, and Commonwealth law, as well as to that of particular European states is taken into account. The author claims that hostility to the concept of good faith in an objective sense in English law is superficial. One may expect that in the near future courts in England and Wales will follow the path taken by courts in the United States ( $\S 205$ of the Restatement (Second) of Contracts (1981)), Australia (Renard Constructions (1992)) and Canada (Bhasin v. Hrynew (2014)), and they will finally recognize good faith as an underlying principle.

Keywords: private law, English law, common law, good faith, abuse of right.

\section{Introduction}

The present paper deals with the contemporary debate on the position of good faith and fair dealing in English law. Despite Lord Mansfield's decision to the contrary ${ }^{1}$, the traditional view discards the recognition of a general principle of good faith in the law of Eng-

Jan Halberda - PhD, Assistant Professor, Jagiellonian University, 9, ul. Golebia, Kraków, 31-007, Poland; jan.halberda@uj.edu.pl

${ }^{1}$ Lord Mansfield in Carter v. Boehm (1766) 3 Burr 1905, 1910. Having stated the insured's duty to disclose all material facts his lordship referred to the principle of utmost good faith (uberrimae fidei).

(๖) St. Petersburg State University, 2021 
land and Wales ${ }^{2}$, it seems that the traditional view stems from English lawyers' treatment of good faith and fair dealing as an overarching principle that enables courts to dispose cases on such standalone basis. Meanwhile, the principle of good faith in an objective sense, along with the concept of the freedom of contract, is one of the most important principles of the continental civil law tradition. Civil lawyers perceive good faith and fair dealing as the underlying principle that works only "in the background" of a legal system providing for justification of particular specific measures to be found in legislation. Other common law jurisdictions do not obediently follow the example of English law: while American courts adopt a general concept of good faith so far as it concerns performance of contract, the law in such Commonwealth jurisdictions as Australia and Canada is not yet settled. The current paper analyses recent English case law that seems to acknowledge the duty of good faith and fair dealing as a term implied in fact, while rejecting the traditional view mentioned above. The comparative approach - references to American, and Commonwealth law, as well as to that of particular European states - is taken into account. My argument is that hostility to the concept of good faith in an objective sense in English law is superficial. One may expect that in the near future courts in England and Wales will recognize good faith as an underlying principle.

\section{Two meanings of good faith}

Continental civil law scholarship applies the concept of good faith in either a subjective or objective sense. The present paper focuses on the latter one, as an example of a general clause (open norm) that provides for a "safety valve" for a legal system. On the one hand, good faith in an objective sense might be equated with a prohibition against the abuse of right ${ }^{3}$. Both concepts seem to be the obverse and reverse of the same phenomenon.

On the other hand, good faith in a subjective sense refers to the state of a party's knowledge (honesty and fairness in mind), and permits the law to protect it if the party in question acted under a justified mistake as to its entitlement ${ }^{4}$. Good faith in a subjective sense has been recognized in Anglo-American law ${ }^{5}$ - at least in property law: a bona fide purchaser for value acquires title despite the fact that the seller was not authorised to dispose it ${ }^{6}$. Still, particular legal doctrines refer to other concepts such as reliance in-

2 Cf. the authors referred to in the footnote 14 below: McKendrick E., Liu Q. Good faith in contract performance in the Chinese and common laws // Chinese contract law: Civil and common law perspectives / eds L. DiMatteo, C. Lei. Cambridge: Cambridge University Press, 2017. P. 72; Teubner G. Legal irritants: Good faith in British law or How unifying law ends up in new divergences // Modern Law Review. 1998. Vol.61. P. 11. - While Teubner refers to good faith in common law as "the infecting virus", "a contagious disease of alien origin", McKendrick and Liu call it "something of a problem child".

3 To some extent good faith in this sense corresponds with what some scholars refer to as a "bad faith excluder": MacQueen H. Good faith, PECL and mixed systems // University of Edinburgh School of Law Research Paper Series. 2018. No. 27. P. 29 (referring to mixed jurisdictions); Stapleton J. Good faith in private law // Current Legal Problems. 1999. Vol. 52. P.7-8 (English law); Summers R. S. The general duty of good faith - its recognition and conceptualization // Cornell Law Review. 1981-1982. Vol.67. P.823 (American law).

4 Schmidt J.P. Good faith and fair dealing // Commentaries on European contract laws / eds. N. Jansen, R. Zimmermann. Oxford: Oxford University Press, 2018. P. 103-104.

5 Stapleton J. Good faith in private law. P. 11, 24. - Stapleton refers to "the norm of good faith" and "actual good faith"; these concepts correspond with good faith in objective and subjective senses respectively.

6 Gordley J. Foundations of Private Law. Property, Tort, Contract, Unjust Enrichment. Oxford: Oxford University Press, 2010. P. 49-50; Gray K. Elements of land law. London: Butterworths, 1993. P. 5ff, 51-53, 68-75; Milo J. M. Property and real rights // Elgar Encyclopedia of Comparative Law / ed. by J. M. Smits. 
stead of good faith. In English law, estoppel by acquiescence requires that the party acts in reliance. This corresponds with the good faith (in a subjective sense) that is to be found in Polish law in cases of either positive prescription (art. 172 of the Civil Code (hereinafter CC) of 1964) ${ }^{7}$, or of improvements made on another's property (art. 224ff of the CC). English reliance, as well as Polish good faith, is proven if the possessor remained in a false, but justified (in circumstances of the case), impression that the legal title is vested in him $^{8}$.

\section{The orthodox view in English law}

The starting point of discussion on the unified principle of good faith and fair dealing in England (and Wales) is that there is no such concept present there. It does not mean, however, that there are no "safety valves" in English law. In past centuries, it was the chancellor who developed equity law. Like the ius praetorium to the Roman ius civile, equity law was a gloss to common law. The chancellor's jurisdiction was to fill the (axiological) lacunae of common law and to ease the severity of rigid rules found in the basic legal system. Still today, though to a limited extent, equity law prevents unconscionable reliance on legal rights ${ }^{9}$.

Today, instead of having a unitary principle of good faith and fair dealing, English courts resort to a number of specific legal doctrines that implement fairness and prevent abuse of right. English law has already adopted, nolens volens, the principle of good faith and fair dealing in respect to consumer law in the course of the United Kingdom's implementation of European directives ${ }^{10}$. Other examples include duty of good faith and fair dealing as a term implied by law in such fields as insurance law ("duty of utmost good faith") ${ }^{11}$ or employment law. In addition to scarce statutory regulations, a number of solutions have been incrementally developed by courts: rules for the construction of contracts (including rectification ${ }^{12}$ and implied terms ${ }^{13}$ ), doctrines of frustration of contract, economic duress, undue influence, unconscionable bargain, or fiduciary duty. These specific

Cheltenham: Edward Elgar Publishing, 2006. P. 593-596; Stapleton J. Good faith in private law. P. 14 (several other examples are added, including a change of position in the law of unjust enrichment).

7 The Act of 23 April 1964 - The Civil Code. Available at: http://isap.sejm.gov.pl/isap.nsf/DocDetails.xsp?id=WDU20200001740 (accessed: 30.01.2021).

8 Halberda J. Estoppel w angloamerykańskim prawie prywatnym [Estoppel in Anglo-American Private Law]. Kraków: Księgarnia Akademicka, 2020. P. 226.

${ }^{9}$ Etherton T. Equity and conscience, Northumbria University - Eldon Professor's Lecture, 25 October 2017. P. 1-2. Available at: www.judiciary.gov.uk/wp-content/uploads/2017/10/sir-terence-etherton-mreldon-lecture-20171030.pdf (accessed: 30.01.2021); Harding M. Equity and the Rule of Law // The Law Quarterly Review. 2016. Vol. 132. P. 296, 302.

10 In particular, the provisions of the Council Directive 93/13/EEC of 5 April 1993 on Unfair Terms in Consumer Contracts were introduced into domestic law by The Unfair Terms in Consumer Contracts Regulations 1994 sch. 2 (SI 1994/3159), recently replaced by The Consumer Rights Act 2015 c. 15, s. 62; Collins H. Good faith in European contract law // Oxford Journal of Legal Studies. 1994. Vol. 14. P. 249-254.

11 Lord Mansfield in Carter v. Boehm (1766) 3 Burr 1905, 1910.

12 Arden LJ. in Ahmad v. Secret Garden (Cheshire) Ltd. (2013) EWCA Civ 1005 § 28: "Rectification is, in a sense, an instance of English and Welsh law applying a concept of good faith (that is, fair dealing) without actually calling it such".

13 Hildyard LJ. (with whom Longmore and Jackson LJJ. agreed) in Dixon \& Anor v. Blindley Heath Investments Ltd. \& Anor (2015) EWCA Civ $102 \S 80$ commenting on principles of estoppel by convention "which are self-evidently a matter of good faith and fair dealing". In such English cases that call for estoppel by convention (Amalgamated Investment \& Property Co. Ltd. v. Texas Commerce International Bank Ltd. (1982) QB 84), Polish courts would apply the provisions on the construction of contracts (art. 62 of the CC). 
legal doctrines are referred to as piecemeal solutions following the notion coined by Bingham LJ ${ }^{14}$.

Estoppel is one of the most frequently mentioned piecemeal solutions preventing the abuse of right (without specifically referring to it as such). A significant number of promissory estoppel or promise-based proprietary estoppel cases occur in English courts in reaction to the formalism and rigidity of particular legal doctrines, such as consideration (Central London Property Trust Ltd. v. High Trees House Ltd. (1947), Collier v. P \& MJ Wright (Holdings) Ltd. (2008)), statute of frauds (Yaxley v. Gotts (2000)), registration (Taylors Fashions Ltd. v. Liverpool Victoria Trustees Co. Ltd. (1982)), or statute of limitations (cf. Australian case of Commonwealth v. Verwayen (1990)) ${ }^{15}$. Promissory estoppel comes into the spotlight if a promisor who had assured that he would abstain from resorting to his strict contractual rights changes his mind and attempts to withdraw his promise (Hughes v. Metropolitan Rly Co. (1877)) ${ }^{16}$. In Poland such cases call for application of the prohibition against the abuse of law (art. 5 of the $\mathrm{CC}$ ), or for the rule ordering the party to cooperate with its contractor pursuant to a socio-economic purpose of the right (in Polish: społeczno-gospodarcze przeznaczenie prawa) and with the principles of social coexistence (in Polish: zasady współżycia społecznego) (art. 354 of the CC). In other civil law jurisdictions, similar general clauses would be taken into account ${ }^{17}$. On English soil, promissory estoppel plays the same role as the principle of good faith and fair dealing does on the Continent.

In the last years of the $20^{\text {th }}$ century, it seemed that the position of English law on the concept of good faith and fair dealing was clear. There was an incontestable communis opinio denying the presence of said principle - not only in negotiations (Lord Ackner in Walford v. Miles (1992)) ${ }^{18}$ but also in performance of contracts (Bingham LJ. in Interfoto Picture Library Ltd. v. Stiletto Visual Programs Ltd. (1987)) ${ }^{19}$.

14 Bingham LJ. in Interfoto Picture Library Ltd. v. Stiletto Visual Programmes Ltd. (1987) EWCA Civ 6; Breskaya M. Good faith matters? English contract law tradition compared to the directions of EU private law // Studia Prawa Prywatnego. 2018. No. 1. P.91, 93; Collins H. Implied terms: The foundation in good faith and fair dealing // Current Legal Problems. 2014. Vol. 67. P. 18-35; McKendrick E. Contract law. Text, cases, and materials. Oxford: Oxford University Press, 2018. P. 6, 482ff; McKendrick E., Liu Q. Good faith in contract performance in the Chinese and common laws. P. 72-75; McMeel G. Foucault's pendulum: Text, context and good faith in contract law // Current Legal Problems. 2017. Vol. 70. P. 26; Schmidt J. P. Good faith and fair dealing. P. 125-126; Whittaker S. Introduction // Chitty on Contracts / ed. by H. Beale. $31^{\text {st }}$ ed. Vol. 1: General Principles. London: Sweet \& Maxwell Ltd., 2012. P. 31ff; Zimmermann R., Whittaker S. Good faith in European contract law. Cambridge: Cambridge University Press, 2008. P. 45-47.

15 Central London Property Trust Ltd. v. High Trees House Ltd. (1947) KB 130; Collier v. P \& MJ Wright (Holdings) Ltd. (2008) 1 WLR 643; Commonwealth v. Verwayen (1990) 170 CLR 394; Taylors Fashions Ltd. v. Liverpool Victoria Trustees Co. Ltd., Old \& Campbell Ltd. v. Liverpool Victoria Friendly Society (1982) QB 133; Yaxley v. Gotts (2000) Ch 162.

${ }^{16}$ Hughes v. Metropolitan Rly Co. (1877) 2 AC 439.

17 Ranieri F. Good faith // The Max Planck Encyclopedia of European private law / ed. by J. Basedow. Oxford, 2014. P. 792.

18 Lord Ackner in Walford v. Miles (1992) 64 P\&CR 166, 173: "the concept of a duty to carry on negotiations in good faith is inherently repugnant to the adversarial position of the parties when involved in negotiations"). While the decision rejects the implied condition of duty to negotiate in good faith, Lord Leggatt extra-judicially asks why the parties should not be allowed to introduce an express condition that would limit their freedom to leave the negotiating table (Leggatt G. Negotiation in good faith: Adapting to changing circumstances in contracts and English contract law // Journal of Business Law. 2019. No. 2. P. 113).

19 Bingham LJ. in Interfoto Picture Library Ltd. v. Stiletto Visual Programmes Ltd. (1987) EWCA Civ 6; Atiyah P. S., Smith S. Atiyah's introduction to the law of contract. Oxford: Oxford University Press, 2005. P. 164; Beale H. et al. Cases, materials and text on contract law. lus commune casebooks for the common law of Europe. Oxford; Portland: Hart Publ., 2010. P. 931; Beatson J., Friedmann D. From "classical" to modern contract law // Good faith and fault in contract law / eds J. Beatson, D. Friedmann. Oxford: Oxford University Press, 2002. P. 11; Burrows A. A restatement of the English law of contract. Oxford: Oxford Uni- 
Those decisions were in line with previous English case law contesting the recognition of both the principle of good faith (in an objective sense) and the prohibition against the abuse of rights. Leading cases were Crofter Hand Woven Harris Tweed Co. v. Veitch (1942) and two older rulings cited in extenso in that decision: Bradford Corporation v. Pickles (1895), and Allen v. Flood (1898). In these cases, tort claims were unsuccessfully made to counter the negative effects of defendants' conduct. In the oldest one, a defendant, in order to persuade a plaintiff (local community) to purchase his property, diverted the course of a river and thus deprived the vicinity of access to clear water. In neighbourhood relations similar to this case, an effective protection measure could sometimes be a tort of nuisance. However, it did not always lead to a satisfactory goal. In two subsequent cases, defendants prompted third parties to terminate or not conclude contracts with plaintiffs. These cases started in consequence of trade unions' chicanes against non-union employees or competition fights between entrepreneurs. In reaching the decision in Crofter Hand (1942), Lord Wright pointed out that, unless the party perpetrates acts explicitly prohibited by law, the motive of these acts is irrelevant under English law. When making the opinion about the absence of the principle of good faith and fair dealing in English law, the same conclusion - most often implicit - was reached regarding the prohibition against the abuse of right ${ }^{20}$.

Piecemeal solutions operated as an exception. In White and Carter (1961) the question arose as to whether in the event of a debtor's breach of contract a creditor's freedom to elect a remedy was limited. Was the latter one free to choose between claiming a contract's performance in kind or a payment of compensation? Lord Reid rejected the concept of creditors' arbitrariness. His Lordship pointed out that if among the available alternatives, the creditor chose the one that did not provide a measurable benefit (legitimate interest) but led to a debtor's particular disadvantage, such an election should not enjoy legal protection. Despite his statement's being an obiter dictum, the courts approved it in subsequent decades. Importantly, these later references did not go beyond the issue considered by Lord Reid in 1962, i. e. whether a contract's enforcement in kind can be requested in lieu of compensation ${ }^{21}$. While this happened to a limited extent, note that Lord Reid had introduced into English contract law the argumentation that is resorted to in events of prohibition against the abuse of law in civil law jurisdictions.

versity Press, 2016. P. 69, 93; Cartwright J. Contract law. An introduction to the English law of contract for the civil lawyer. Oxford: Hart Publ., 2007. P. 64-67; Cartwright J., Hesselink M. Precontractual liability in European private law. Cambridge: Cambridge University Press, 2008. P. 66-67, 166-168, 451, 465-466; Collins H. Implied terms. P. 3-4; McKendrick E., Liu Q. Good faith in contract performance in the Chinese and common laws. P. 482ff; McMeel G. Foucault's Pendulum: Text, Context and Good Faith in Contract Law // Current Legal Problems. 2017. Vol.70. P. 2, 22; Ranieri F. Good faith. P. 792; Schmidt J. P. Good faith and fair dealing. P. 124-126; Whittaker S. Introduction. P. 31ff; Zimmermann R., Whittaker S. Good faith in European contract law. P. 39-41.

20 Bradford Corporation v. Pickles (1895) UKHL 1; Allen v. Flood (1898) AC 1; Lord Wright in Crofter Hand Woven Harris Tweed Co. v. Veitch (1942) AC 435, 468: "the rule is as well established in English law as I here take to be the rule that motive is immaterial in regard to the lawful act of an individual"; Beale $\mathrm{H}$. et al. Cases, materials and text on contract law. P. 931; Gutteridge H. C. Abuse of rights // Cambridge Law Journal. 1933-1935. Vol. 5. P. 22, 30; Perillo J. Abuse of rights. A pervasive legal concept // Pacific Law Journal. 1995. Vol. 27. P. 40-42; Ranieri F. Abuse of right // The Max Planck Encyclopedia of European private law / ed. by J. Basedow. Oxford: Oxford University Press, 2014. P. 5; Schmidt J. P. Good faith and fair dealing. P. 124; Watts P. Taxonomy in private law — furor in text and subject// New Zealand Law Review. 2014. P. 132.

21 White and Carter (Councils) Ltd v. McGregor (1961) UKHL 5 (BalLII); Stocznia Gdanska SA v. Latvian Shipping Co. (1996) CLC 1410, 1417; Isabella Shipowner SA v. Shagang Shipping Co. Ltd. (The Aquafaith) (2012) 1 CLC 899, 903-907; Moore-Bick LJ. in MSC Mediterranean Shipping Company SA v. Cottonex Anstalt (2016) EWCA Civ 789 § 29-33, 45 (Moore-Bick LJ. draws attention to the fact that the presence of such piecemeal solutions as the one applied by Lord Reid takes away the need to acknowledge the general principle of good faith in English law). 


\section{A new approach in English law}

Although the starting point still remains the same (the lack of the principle of good faith and fair dealing in English law ${ }^{22}$ due to the binding force of precedent ${ }^{23}$ ), the status of the principle in question is currently the subject of lively discussion. This is because various parties have begun to introduce into their contracts express conditions that require contractors to act in good faith (in an objective sense) while they construct (interpret) or perform a contract ${ }^{24}$, as well as in cases of reviews (renegotiations) of contract conditions. Simultaneously, in recent years there are more and more judicial opinions that call for recognition of good faith and fair dealing as an implied term of a contract's performance ${ }^{25}$.

Research indicates that discussion of the principle of good faith and fair dealing (not always leading to its recognition) takes place in cases dealing with negotiations that did not lead to the conclusion of any contract ${ }^{26}$, cooperation in performance of a contract ${ }^{27}$, issues of contract construction and existence of duty of loyalty between parties ${ }^{28}$, interpretation of contracts contrary to an Entire-Agreement Clause (EAC, merger clause) ${ }^{29}$, freedom of one of the parties to exercise contractual provisions conferring special rights on it ${ }^{30}$, modification of contracts that are non-compliant with statute of frauds or contrary to No Oral Modification (NOM) clauses ${ }^{31}$, or - more generally - the effects of inconsistent conduct of one of the parties.

Among the leading supporters of the principle's recognition is Lord Leggatt who has recently (in April 2020) been appointed to the Supreme Court of the United Kingdom ${ }^{32}$, In Yam Seng Pte Ltd. v. International Trade Corp Ltd. (2013) he advocated for the adoption

22 Jackson LJ. in Mid Essex Hospital Services NHS Trust v. Compass Group UK and Ireland Ltd. (t/a Medirest) (2013) EWCA Civ $200 \S 105$ : "there is no general doctrine of 'good faith' in English contract law, although a duty of good faith is implied by law as an incident of certain categories of contract"; Norris J. in Hamsard 3147 Ltd. (t/a Mini Mode Childrenswear) \& Anor v. Boots UK Ltd. (2013) EWHC 3251 (Pat) § 85-87, 92; Moore-Bick LJ. (§ 45) and Tomlison LJ. (§ 60) in MSC Mediterranean Shipping Company SA v. Cottonex Anstalt (2016) EWCA Civ 789; Collins H. Implied terms. P. 18-35; Tolen L. Implied good faith - lost at sea following court of appeal shipping case? Available at: www.law.ox.ac.uk/business-law-blog/blog/2016/10/ implied-good-faith-lost-sea-following-court-appeal-shipping-case (accessed: 30.01.2021).

23 Interfoto Picture Library Ltd. v. Stiletto Visual Programmes Ltd. (1987) EWCA Civ 6; Walford v. Miles (1992) 64 P\&CR 166.

24 Mid Essex Hospital Services NHS Trust v. Compass Group UK and Ireland Ltd. (t/a Medirest) (2013) EWCA Civ 200; Kabab-Ji SAL (Lebanon) v. Kout Food Group (Kuwait) (2020) EWCA Civ 6.

25 Leggatt G.: 1) Contractual duties of good faith. Lecture to the Commercial bar association on 18 October 2016. P.2-4, 8-15. Available at: www.judiciary.uk/announcements/speech-by-mr-justice-leggattcontractual-duties-of-good-faith (accessed: 30.01.2021); 2) Negotiation in good faith. P. 106-107, 114.

26 Walford v. Miles (1992) 64 P\&CR 166, 173.

27 Yam Seng Pte Ltd. v. International Trade Corp Ltd. (2013) 1 CLC 662, 700; Mid Essex Hospital Services NHS Trust v. Compass Group UK and Ireland Ltd. (t/a Medirest) (2013) EWCA Civ 200; Ted Baker Plc v. Axa Insurance UK PIc (2017) EWCA Civ 4097.

28 Yam Seng Pte Ltd. v. International Trade Corp Ltd. (2013) 1 CLC 662, 694-701.

29 Peekay Intermark Ltd. v. Australia \& New Zealand Banking Group Ltd. (2006) 1 CLC 582, 602; Springwell Navigation Corp. v. JP Morgan Chase Bank (2010) EWCA Civ 1212.

30 Interfoto Picture Library Ltd. v. Stiletto Visual Programmes Ltd. (1987) EWCA Civ 6. However, the general duty to act in good faith cannot prevail over the terms of contract that prescribe in detail how to apply deductions and penalties (Jackson LJ. (§ 104-106) and Beatson LJ. $(\S 152,154)$ in Mid Essex Hospital Services NHS Trust v. Compass Group UK and Ireland Ltd. (t/a Medirest) (2013) EWCA Civ 200).

31 Rock Advertising Limited (Respondent) v. MWB Business Exchange Centres Limited (Appellant) (2018) 1 CLC 946, 955; Kabab-Ji SAL (Lebanon) v. Kout Food Group (Kuwait) (2020) EWCA Civ 6 § 77 (a clause demanding construction and interpretation of a contract in good faith cannot overcome an explicit NOM clause).

32 COVID-19: Swearing-in ceremony for Leggatt LJ to Supreme Court "significantly modified". Available at: https://uk.practicallaw.thomsonreuters.com/w-025-0588?transitionType=Default\&contextData= (sc.Default)\&firstPage $=$ true \&bhcp $=1$ (accessed: 30.01 .2021 ). 
of an implied in fact term of good faith and fair dealing in cases of long-term contracts (referred to as "relational" contracts) that "require a high degree of communication, cooperation and predictable performance based on mutual trust and confidence and involve expectations of loyalty which are not legislated for in the express terms of the contract but are implicit in the parties' understanding and necessary to give business efficacy to the arrangements", such as joint venture agreements, franchise agreements, and long-term distributorship agreements. While the content of the duty based on an implied term of good faith and fair dealing depends on the circumstances of the case, Leggatt J. (as he was then known) formulated the test "whether in the particular context the conduct would be regarded as commercially unacceptable by reasonable and honest people"33.

An analogy can be found between the implied duty of good faith and fair dealing understood in such a way, and the prohibition against the abuse of right. This recalls the view applied under American law (the concept of good faith as a "bad faith excluder") and raises another question: what could be a source for a possible change of heart in England would it more likely be American influence, or European? In Yam Seng (2013) Leggatt J. resorted to comparative argumentation drawing attention to American sources such as the Uniform Commercial Code (UCC), and the Restatement (Second) of Contracts, as well as to the European harmonization projects - Principles of European Contract Law (PECL), and Common European Sales Law (CESL) ${ }^{34}$.

\section{Commonwealth and American law jurisdictions}

Despite the United Kingdom's "splendid isolation", English law is closely linked to the laws of Commonwealth jurisdictions and, to a lesser extent, to American law ${ }^{35}$. The analysis of decisions made in such hard cases as Yam Seng (2013), indicates that English courts often resort to the use of arguments based on comparative law. Within the profession, it is accepted that the Australian law should be considered when analysing the English law. The law of obligations in both jurisdictions did not differ much until the mid-twentieth century. Change occurred only later as a result of the United Kingdom's accession to the European Communities. Despite this, even today decisions issued in one jurisdiction enjoy the force of persuasive precedent in another ${ }^{36}$. The ties between English and Commonwealth jurisdictions will most certainly tighten after Brexit.

33 Yam Seng Pte Ltd. v. International Trade Corp Ltd. (2013) 1 CLC 662, 699. Other statements that advocate in favour of recognition of the principle are: Ted Baker Plc v. Axa Insurance UK Plc (2017) EWCA Civ 4097); Bogle S. Disclosing good faith in English contract law // The Edinburgh Law Review. 2014. Vol. 18 (1). P. 141-145 (good faith as an underlying principle justifying current legal doctrines and not an overarching principle that modifies the law); Stapleton J. Good faith in private law. P. 5, 25; Steyn J. Contract law: Fulfilling the reasonable expectations of honest men // The Law Quarterly Review. 1997. Vol. 113. P. 438-439. - For good faith as the underlying principle in Scots Law cf.: MacQueen H. Good faith, PECL and mixed systems. P. 18.

34 Yam Seng Pte Ltd. v. International Trade Corp. Ltd. (2013) 1 CLC 662, 695-696.

35 The need to include a wide comparative background while conducting studies of English law is not questioned in legal literature: Robertson A., Tilbury M. Unity, divergence and convergence in the common law of obligations // The common law of obligations: Divergence and unity / eds A. Robertson, M. Tilbury. Oxford; Portland: Hart Publ., 2016. P. 1ff; Bankowski Z., MacCormick D. N., Marshall G. Precedent in United Kingdom // Interpreting precedents. A comparative study / eds D. N. MacCormick, R. S. Summers. London; New York: Routledge, 2016. P. 327.

${ }^{36}$ Beatson J., Friedmann D. From "classical" to modern contract law. P. 3; Burrows $A$. The influence of comparative law on the English law of obligations // The common law of obligations: Divergence and unity / eds A. Robertson, M. Tilbury. Oxford; Portland: Hart Publ., 2016. P. 18, 32-33; Kirby M. Legal obligations. Legal revolutions // The Law Quarterly Review. 2018. Vol. 134. P. 43, 48, 51; Mason A. Future directions in Australian law // Monash University Law Review. 1987. Vol. 13. P. 149-150; Willmott L. et al. Contract Law. Oxford: Oxford University Press, 2018. P. 8-13. 
Disputes dealing with the status of the principle of good faith and fair dealing are ongoing in Australia and Canada (except Quebec where the principle is being recognized in art. 6 of the Civil Code of Québec) $)^{37}$. Although the law in these common law jurisdictions is not yet settled, it seems that its development is leading toward the recognition of such a principle. It has been accepted in Australia that a party entrusted with special rights allowing it to assess another party's performance should exercise such contractual rights reasonably viz. in good faith ${ }^{38}$. Following the lead of the American and Quebec examples, the recent decision of the Supreme Court of Canada in Bhasin v. Hrynew (2014) adopted the duty of good faith and fair dealing in the performance of contracts as a term implied in law (the duty of honest performance) ${ }^{39}$. While the parties to a contract might decide to exclude an implied term of good faith and fair dealing if it is a term implied in fact (Yam Seng (2013)), they are not allowed to do so in cases of term implied in law (Bhasin v. Hrynew (2014)).

The status of the principle of good faith and fair dealing seems to be settled under the laws of the various American states. The first difference that catches the eye is the presence of a general principle of good faith and fair dealing in the performance (but not in the negotiation) of contracts. The principle was first recognized in the Uniform Commercial Code (art. 1-201 (20), art. 1-304), wherein good faith was equated with "honesty in fact and the observance of reasonable commercial standards of fair dealing", and later in the Restatement (Second) of Contracts $(\S 205)^{40}$. The former one was introduced in the second half of the $20^{\text {th }}$ century in all American states, including in Louisiana which is an example of mixed jurisdiction, while the latter one (adopted in 1981), although only an example of soft law, enjoys exceptionally high authority. It seems that the said principle is understood by American courts and legal literature in a similar way as the prohibition against the abuse of right is being applied in Europe. In Louisiana, the duty of good faith and fair dealing in the law of obligations is even explicitly expressed in the provision of art. 1759 of the Louisiana Civil Code ${ }^{41}$. However, American law does not provide for the application of the said principle at the pre-contractual stage, viz. during negotiations ${ }^{42}$.

${ }^{37}$ Civil Code of Québec. Available at: legisquebec.gouv.qc.ca/en/showdoc/cs/CCQ-1991 (accessed: 30.01 .2021 ).

38 Renard Constructions (ME) Pty Ltd. v. Minister for Public Works (1992) 26 NSWLR 234; Douglas J. England as a source of Australian law: For how long? // Australian Law Journal. 2012. Vol. 86. P. 347; Leggatt G. Negotiation in good faith. P. 115.

${ }^{39}$ Bhasin v. Hrynew (2014) SCC $71 \S$ 73-80. Followed recently in C. M. Callow Inc. v. Zollinger (2020) SCC 45; Maharaj K. An action on the equities: Re-characterizing Bhasin as equitable estoppel // Alberta Law Review. 2017. Vol.55. P. 199ff; Waddams S. Good faith, good conscience, and the taking of unfair advantage // Defences in contract / eds A. Dyson, J. Goudkamp, F. Wilmot-Smith. Oxford; Portland: Hart Publ., 2017. P. 83-86.

40 Northwest, Inc. v. Ginsberg (2014) 572 US 273; Farnsworth A.: 1) Good faith in contract performance // Good faith and fault in contract law / eds J. Beatson, D. Friedmann. P. 155; 2) Contracts. Boston; Toronto: Little, Brown, 1990. P. 550; Knapp C.L. Reliance in the revised restatement: The proliferation of promissory estoppel // Columbia Law Review. 1981. Vol. 81. P. 78; Mattar M. Y. Promissory estoppel: Common law wine in civil law bottles // Tulane Civil Law Forum. 1988. Vol. 4. P. 116-117; Metzger M. B., Phillips M. J. Promissory estoppel and the evolution of contract law // American Business Law Journal. 1980. Vol. 18. P. 174; Perillo J. Abuse of rights. P. 87; Summers R. S. The general duty of good faith - its recognition and conceptualization. P. 823 (good faith as a "bad faith excluder", i. e. the prohibition against the abuse of right). There was no similar provision in the Restatement (First) of Contracts.

41 Louisiana Civil Code. Available at: www.legis.la.gov/legis/Laws_Toc.aspx?folder=67\&level=Parent (accessed: 30.01.2021).

42 Market Street Associates Limited Partnership v. Frey (1991, $7^{\text {th }}$ Cir) 941 F. 2d 588; Farnsworth A.: 1) Good faith in contract performance. P. 155; 2) Contracts. P. 550; Knapp C. L. Reliance in the revised restatement. P. 78; Metzger M. B., Phillips M. J. Promissory estoppel and the evolution of contract law. P. 174; Perillo J. Abuse of rights. P. 87; Pierson J. F., Jr. Contracts - consideration - promissory estoppel // Louisiana Law Review. 1955. Vol. 15. P. 820-823; Scott R. E. Hoffman v. Red Owl Stores and the myth of precontractual 


\section{Civil law jurisdictions}

Meanwhile, in the European civil law tradition it is assumed that the principle of good faith and fair dealing is one of the most important principles of private law in general and of contract law in particular. Good faith in an objective sense introduces equitable elements into the law by ordering the court to assess the parties' conduct from the perspective of a specific extra-legal model (fairness, honesty, decency). In other words, it plays the role of a "safety valve" in private law 43 .

There are plenty of general clauses in the laws of continental Europe that require a specific assessment pattern (which is often that of good faith and fair dealing) to be applied by the courts. In several civil codes, such clauses provided for a rather narrow field of application as did the provisions of art. $1134 \S 3$ (performance of contracts) and art. 1135 (content of contracts) in the French Code Civil before its recent amendment in 2016, and as do those of $\S 157$ (interpretation of contracts) and $\S 242$ (Treu und Glauben; performance of duties) ${ }^{44}$ in the German BGB. Elsewhere, they have much wider scope of application, cf. art. 2 (1) of the Swiss Zivilgesetzbuch (the general good faith and fair dealing clause), art. 6:2 of the Dutch Burgerlijk Wetboek (the standards of reasonableness and fairness in law of obligations ${ }^{45}$ ), art. 1104 of the French Code Civil after its amendment in 2016 (the good faith and fair dealing clause in contract law ${ }^{46}$ ), or art. 5 of the Polish Civil Code (the prohibition against the abuse of right).

European harmonization projects, such as Principles of European Contract Law (PECL), Draft Common Frame of Reference (DCFR), and Common European Sales Law (CESL), resort to the concept of "good faith and fair dealing" which corresponds to good faith in an objective sense. While the scope of application of art. 2 (1) CESL refers to both pre-contractual and performance phases, art. 1:201 PECL and art. III-1:103 DCFR otherwise apply only to the latter one, leaving the former one for separate regulation under

reliance // Contract stories / ed. by D. G. Baird. New York: Foundation Press; Thompson West, 2007. P.77, 90-91; Summers R. S. The general duty of good faith - its recognition and conceptualization. P. 823 .

${ }^{43}$ Safjan M. Klauzule generalne w prawie cywilnym (przyczynek do dyskusji) [The General Clauses in Civil Law (Contribution to Discussion)] // Państwo i Prawo. 1990. No. 11. P. 54; Schmidt J. P. Good faith and fair dealing. P. 103-104, 140.

44 Despite its location in the part dealing with the law of obligations, the provision of $\S 242$ applies now to all fields of private law. It has much broader range of application than the literal wording might suggest: Ebke W. F., Steinhauer B.M. The doctrine of good faith in German contract law // Good faith and fault in contract law / eds J. Beatson, D. Friedmann. P. 171-174; Gutteridge H. C. Abuse of rights. P. 36-39; Gerven W. van, Lever J., Larouche P. Tort law. Common law of Europe casebooks. Oxford; Portland: Hart Publ., 2000. P. 231-235, 736; Markesinis B. S., Unberath H. The German law of torts: A comparative treatise. Oxford; Portland: Hart Publ., 2002. P. 369, 889, 908; Markesinis B. S., Unberath H., Johnston A. The German law of contract: A comparative treatise. Oxford; Portland: Hart Publ., 2006. P. 85-99, 122-126; Schmidt J. P. Good faith and fair dealing. P. 113-116; Zimmermann R., Whittaker S. Good faith in European contract law. P. 24-25, 30.

45 Hondius E. H., Van Kooten H. J. The principles of European contract law and Dutch law: A commentary. The Hague: Kluwer Law International, 2002. P. 47ff; Rott-Pietrzyk E. Holenderska klauzula rozsądku i słuszności na tle innych uregulowań prawnych (wzór dla polskiego ustawodawcy?) [The Dutch clause of reasonableness as compared with other legal systems (A model for the Polish legislator?)] // Studia Prawa Prywatnego. 2006. No. 3. P. $60 \mathrm{ff}$.

46 The Law of Contract, The General Regime of Obligations, and Proof of Obligations. The new provisions of the Code civil created by Ordonnance n ${ }^{\circ}$ 2016-131 of 10 February 2016 / transl. by J. Cartwright, B. Fauvarque-Cosson, S. Whittaker. Available at: www.textes.justice.gouv.fr/art_pix/THE-LAW-OF-CONTRACT-2-5-16.pdf (accessed: 30.01.2021); Civil Code of the Netherlands. Available at: www.dutchcivillaw. com/civilcodegeneral.htm (accessed: 30.01.2021); German Civil Code. Available at: www.gesetze-iminternet.de/englisch_bgb (accessed: 30.01.2021); Swiss Civil Code. Available at: www.admin.ch/opc/en/ classified-compilation/19070042/201801010000/210.pdf (accessed: 30.01.2021). Cf. articles 6 and 7 of the Civil Code of the People's Republic of China adopted in 2020. Available at: http://english.www.gov.cn/ atts/stream/files/5feda5b8c6d0cc300eea77ac (accessed: 30.01.2021). 
art. 2:301 and art. II-3:301 (2) respectively of these projects. The provisions of art. 5:102 (g) PECL, art. II-8:102 (1) (g) DCFR and art. 59 (h) CESL require that good faith be taken into account when interpreting contracts ${ }^{47}$.

\section{Conclusion: The future of English law}

The main argument against the principle of good faith and fair dealing in English law is the fear of palm tree justice ${ }^{48}$. Those English lawyers who discard the principle consider it as an independent cause of action that allows the court to arbitrarily establish rights and duties of the parties. The principle, if understood in such a way - as an overarching principle - indeed entails uncertainty of law and unpredictability of court decisions. It brings therefore the nightmare of palm tree justice and thus threatens the most important values of the legal system.

However, the recognition of the principle in continental legal systems does not mean that disputes between the parties are settled arbitrarily. The principle works only "in the background" of a legal system (as an underlying principle) providing for justification of particular specific measures to be found in legislation. It operates hand in hand with another fundamental principle of contract law, namely the freedom of contract. The concept of good faith in an objective sense assists lawyers in the proper construction of contracts, supplements the content of legal relations, compels a creditor to cooperate with a debtor in a contract's performance, and under specific circumstances allows a party to evade the effects of his or her legal acts. Last but not least, good faith and fair dealing entails the doctrines of change of circumstances (clausula rebus sic stantibus) and the subsequent impossibility of performance. These are, as the late Lord Bingham might have called it, continental piecemeal solutions, or in the words of German scholars: Fallgruppen. Only in specific circumstances - as a doctrine of last resort - is the principle of good faith and fair dealing applied as an independent legal basis for resolving disputes. One has to bear in mind that such cases of emergency will come much more often today in the days of COVID-19 pandemic and its aftermath.

What, then, is the current status of the principle of good faith and fair dealing in English law? Despite refusing to recognize the principle, English lawyers resort in their everyday practice to a number of specific piecemeal solutions. Thus, it seems that the hostility of English lawyers towards the principle is superficial ${ }^{49}$. In fact, in those cases where an English judge resorts to one of the abovementioned devices, a judge educated in the civil law tradition doesn't apply at once - as his English colleagues might seem to suggest the general principle of good faith and fair dealing, but reaches for one of the specific solutions provided by the domestic civil code.

47 Principles, Definitions and Model Rules of European Private Law: Draft Common Frame of Reference (DCFR) / ed. by C. von Bar. Munich: Sellier, European Law Publ., 2009; MacQueen H. Good faith // European contract law. Scots and South African perspectives / eds H. MacQueen, R. Zimmermann. Edinburgh: Edinburgh University Press, 2006. P. 43; Schmidt J. P. Good faith and fair dealing. P. 101, 106107; Proposal for a Regulation of the European Parliament and of the Council on a Common European Sales Law /* COM/2011/0635 final - 2011/0284 (COD) */. Available at: https://eur-lex.europa.eu/legalcontent/EN/TXT/HTML/?uri=CELEX:52011PC0635\&from=pl (accessed: 30.01.2021). While a breach of a duty to act pursuant to good faith and fair dealing results in a claim for damages under CESL, it only allows the party to file a defense under PECL and DCFR. Both latter projects provide for liability for damages only if a party conducts negotiations without an intention to conclude a contract.

48 In other words: the fear of judicial impressionism as referred to by Francois Geny (cited from: Cardozo B. The nature of the judicial process. New Haven: Yale University Press, 1921. P. 138-141). I would like to thank anonymous reviewer for drawing my attention to the notion of le phénomène Magnaud.

49 Leggatt J. in Yam Seng (2013) 701: "I respectfully suggest that the traditional English hostility towards a doctrine of good faith in the performance of contracts, to the extent that it still persists, is misplaced". 
The aversion to the principle of good faith and fair dealing in common law might also have historical roots. The system of procedural writs, which was applicable for centuries, allowed a claimant to demand legal protection provided that he was able to use medieval forms of action (rigid procedural formulas rooted in previous practice). Today a plaintiff has to draw the court's attention to a cause of action, that is a specific legal ground from which he or she derives substantive rights. In the past lawyers used to say ubi remedium ibi ius as a court's view was limited to examining a case only in respect of a claim resulting from a given procedural formula ${ }^{50}$. Still, English lawyers tend to analyse the law from the perspective of isolated procedural writs and forms of action, and not from the angle preferred by continental lawyers, viz. substantive law. Although forms of action were repealed in the $19^{\text {th }}$ century, English law is still suffocating under their influence ${ }^{51}$.

One can draw another (loose) analogy to the distinction already applied by Roman jurists. They distinguished between criticism of law based on equity (aequitas) and the development of law in accordance with clear axiological assumptions within the framework set by law that was based on good faith (bona fides). In this meaning, a civilian concept of good faith and fair dealing, the principles of community life adopted by the Polish Civil Code, or these piecemeal solutions known to English law, are all devices allowing the law to incrementally evolve by absorbing values from extra-legal sources (such as reasonable commercial standards of fair dealing). This is made possible thanks to the high level of legal culture possessed by judges ${ }^{52}$. Still, English lawyers seem to equate the principle of good faith and fair dealing with aequitas, and not with the concept of bona fides as their continental colleagues do.

I think that the question as to whether or not to acknowledge the presence of the principle of good faith and fair dealing in English law should be answered in the affirmative. Even if I am wrong as to the current state of the law (de lege lata), I predict that in coming years, good faith and fair dealing will be recognized as underlying principle ${ }^{53}$. It will operate as a "safety valve" for contract law, a kind of doctrine of last resort that will provide a shield against the abuse of right. This will be of particular interest as Lord Leggatt has been seated on the Supreme Court of the United Kingdom since April 2020. As English courts will gradually enlarge the scope of the principle's application, they will flexibly respond to the hardship caused by widespread impact of the coronavirus.

\section{References}

Atiyah, Patrick Selim, Smith, Stephen. 2005. Atiyah's Introduction to the Law of Contract. Oxford, Oxford University Press.

Baker, John Hamilton. 1990. An introduction to English legal history. London, Boston, Butterworths. Bankowski, Zenon, MacCormick, Donald Neil, Marshall, Geoffrey. 2016. Precedent in United Kingdom. Interpreting precedents. A comparative study, eds MacCormick, Donald Neil, Summers, Robert: 315-354. London, New York, Routledge.

50 Baker J. H. An introduction to English legal history. London; Boston: Butterworths 1990. P. 63-110.

51 Cf. remark made more than a century ago: Maitland F. W. The forms of action at common law. Cambridge: Cambridge University Press, 1962. P. 2.

52 Dajczak W. Doświadczenie prawa rzymskiego a pojęcie dobrej wiary w europejskiej dyrektywie o klauzulach niedozwolonych w umowach konsumenckich [The experience of Roman law and the concept of good faith in the European Directive on unfair clauses in consumer contracts] // Zeszyty Prawnicze UKSW. 2001. No. 1. P.92-93. - One may refer to: Cardozo B. The nature of the judicial process. P. 141: "The judge... is not a knight-errant roaming at will in pursuit of his own ideal of beauty or of goodness. He is to draw his inspiration from consecrated principles".

53 Decision in Pakistan International Airline Corporation v. Times Travel (UK) Ltd (2021) UKSC $40 \S$ 26ff (Lord Hodge) proves that this time did not come yet. 
Bar, Christian von (ed.). 2009. Principles, definitions and model rules of European private law: Draft Common Frame of Reference (DCFR). Munich, Sellier, European Law Publ.

Beale, Hugh, Fauvarque-Cosson, Benedicte, Rutgers, Jacobien, Tallon, Dennis, Vogenauer, Stefan. 2010. Cases, materials and text on contract law. lus commune casebooks for the common law of Europe. Oxford, Portland, Hart Publ.

Beatson, Jack, Friedmann, Daniel. 2002. From "classical" to modern contract law. Good faith and fault in contract law, eds Beatson, Jack, Friedmann, Daniel: 3-24. Oxford, Oxford University Press.

Bogle, Stephen. 2014. Disclosing good faith in English contract law. The Edinburgh Law Review 18 (1): $141-145$.

Breskaya, Maria. 2018. Good faith matters? English contract law tradition compared to the directions of EU private law. Studia Prawa Prywatnego 1: 89-99.

Burrows, Andrew. 2016. A restatement of the English law of contract. Oxford, Oxford University Press.

Burrows, Andrew. 2016. The influence of comparative law on the English law of obligations. The Common law of obligations: Divergence and unity, eds Robertson, Andrew, Tilbury, Michael: 15-33. Oxford, Portland, Hart Publ.

Cardozo, Benjamin. 1921. The nature of the judicial process. New Haven, Yale University Press.

Cartwright, John, Hesselink, Martijn. 2008. Precontractual liability in European private law. Cambridge, Cambridge University Press.

Cartwright, John. 2007. Contract law. An introduction to the English law of contract for the civil lawyer. Oxford, Hart Publ.

Collins, Hugh. 1994. Good faith in European contract law. Oxford Journal of Legal Studies 14: 229-254.

Collins, Hugh. 2014. Implied terms: The foundation in good faith and fair dealing. Current Legal Problems 67: 1-35.

Dajczak, Wojciech. 2001. Doświadczenie prawa rzymskiego a pojęcie dobrej wiary w europejskiej dyrektywie o klauzulach niedozwolonych w umowach konsumenckich. Zeszyty Prawnicze UKSW 1: 79-101.

Douglas, Justice. 2012. England as a source of Australian law: For how long? Australian Law Journal 86: 333-350.

Ebke, Werner, Steinhauer, Bettina. 2002. The doctrine of good faith in German contract law. Good faith and fault in contract law, eds Beatson, Jack, Friedmann, Daniel: 171-190. Oxford, Oxford University Press.

Etherton, Terence. 2017. Equity and conscience, Northumbria University - Eldon Professor's Lecture, 25 October 2017: 1-22. Available at: www.judiciary.gov.uk/wp-content/uploads/2017/10/ sir-terence-etherton-mr-eldon-lecture-20171030.pdf (accessed: 30.01.2021).

Farnsworth, Allan. 1990. Contracts. Boston, Toronto, Little, Brown.

Farnsworth, Allan. 2002. Good faith in contract performance. Good faith and fault in contract law, eds Beatson, Jack, Friedmann, Daniel: 153-170. Oxford, Oxford University Press.

Gerven van, Walter, Lever, Jeremy, Larouche, Pierre. 2000. Tort law. Common law of Europe casebooks. Oxford, Portland, Hart Publ.

Gordley, James. 2010. Foundations of private law. Property, tort, contract, unjust enrichment. Oxford, Oxford University Press.

Gray, Kevin. 1993. Elements of land law. London, Butterworths.

Gutteridge, Harold. 1933-1935. Abuse of rights. Cambridge Law Journal 5: 22-45.

Halberda, Jan. 2020. Estoppel w angloamerykańskim prawie prywatnym. Kraków, Księgarnia Akademicka.

Harding, Matthew. 2016. Equity and the Rule of Law. The Law Quarterly Review 132: 278-302.

Hondius, Ewoud, Van Kooten, Hugo. 2002. The principles of European contract law and Dutch law: A commentary. The Hague, Kluwer Law International.

Kirby, Michael. 2018. Legal obligations. Legal revolutions. The Law Quarterly Review 134: 43-68.

Knapp, Charles L. 1981. Reliance in the revised restatement: The proliferation of promissory estoppel. Columbia Law Review 81: 52-79.

Leggatt, George. 2016. Contractual duties of good faith. Lecture to the Commercial bar association on 18 October 2016: 1-18. Available at: www.judiciary.uk/announcements/speech-by-mrjustice-leggatt-contractual-duties-of-good-faith (accessed: 30.01.2021).

Leggatt, George. 2019. Negotiation in good faith: Adapting to changing circumstances in contracts and English contract law. Journal of Business Law 2: 104-121. 
MacQueen, Hector. 2006. Good faith. European contract law. Scots and South African perspectives, eds MacQueen, Hector, Zimmermann, Reinhard: 43-73. Edinburgh, Edinburgh University Press.

MacQueen, Hector. 2018. Good faith, PECL and mixed systems. University of Edinburgh School of Law Research Paper Series 27: 1-32.

Maharaj, Krish. 2017. An action on the equities: Re-characterizing Bhasin as equitable estoppel. Alberta Law Review 55: 199-224.

Maitland, Frederic William. 1962. The forms of action at common law. Cambridge, Cambridge University Press.

Markesinis, Basil, Unberath, Hannes, Johnston, Angus. 2006. The German law of contract: A comparative treatise. Oxford, Portland, Hart Publ.

Markesinis, Basil, Unberath, Hannes. 2002. The German law of torts: A comparative treatise. Oxford, Portland, Hart Publ.

Mason, Anthony. 1987. Future directions in Australian law. Monash University Law Review 13: 149-163.

Mattar, Mohamed Yehia. 1988. Promissory estoppel: Common law wine in civil law bottles. Tulane Civil Law Forum 4: 71-149.

McKendrick, Ewan, Liu, Qiao. 2017. Good faith in contract performance in the Chinese and common laws. Chinese contract law: Civil and common law perspectives, eds DiMatteo, Larry, Lei, Chen: 72-111. Cambridge, Cambridge University Press.

McKendrick, Ewan. 2018. Contract law. Text, cases, and materials. Oxford, Oxford University Press.

McMeel, Gerard. 2017. Foucault's pendulum: Text, context and good faith in contract law. Current Legal Problems 70: 1-33.

Metzger, Michael, Phillips, Michael. 1980. Promissory estoppel and the evolution of contract law. American Business Law Journal 18: 139-207.

Milo, J. Michael. 2006. Property and real rights. Elgar Encyclopedia of Comparative Law, ed. by Smits, Jan: 587-602. Cheltenham, Edward Elgar Publ.

Perillo, Joseph. 1995. Abuse of rights. A pervasive legal concept. Pacific Law Journal 27: 37-97.

Pierson, James Jr. 1955. Contracts - consideration - promissory estoppel. Louisiana Law Review 15: 820-823.

Ranieri, Filippo. 2014. Abuse of right. The Max Planck Encyclopedia of European private law, ed. by Basedow, Jurgen: 5-7. Oxford, Oxford University Press.

Ranieri, Filippo. 2014. Good faith. The Max Planck Encyclopedia of European private law, ed. by Basedow, Jurgen: 790-794. Oxford, Oxford University Press.

Robertson, Andrew, Tilbury, Michael. 2016. Unity, divergence and convergence in the common law of obligations. The common law of obligations: Divergence and unity, eds Robertson, Andrew, Tilbury, Michael: 1-13. Oxford, Portland, Hart Publ.

Rott-Pietrzyk, Ewa. 2006. Holenderska klauzula rozsądku i słuszności na tle innych uregulowań prawnych (wzór dla polskiego ustawodawcy?). Studia Prawa Prywatnego 3: 57-101.

Safjan, Marek. 1990. Klauzule generalne w prawie cywilnym (przyczynek do dyskusji). Państwo i Prawo 11: 48-59.

Schmidt, Jan Peter. 2018. Good faith and fair dealing. Commentaries on European contract laws, eds Nils, Jansen, Zimmermann, Reinhard: 101-156. Oxford, Oxford University Press.

Scott, Robert E 2007. Hoffman v Red Owl Stores and the myth of precontractual reliance. Contract stories, ed. by Baird, Douglas: 62-93. New York, Foundation Press; Thompson West.

Stapleton, Jane. 1999. Good faith in private law. Current Legal Problems 52: 1-36.

Steyn, Johan. 1997. Contract law: Fulfilling the reasonable expectations of honest men. The Law Quarterly Review 113: 433-442.

Summers, Robert. 1981-1982. The general duty of good faith - its recognition and conceptualization. Cornell Law Review 67: 810-840.

Teubner, Gunther. 1998. Legal irritants: Good faith in British law or How unifying law ends up in new divergences. Modern Law Review 61: 11-32.

Tolen, Liam. 2016. Implied good faith - lost at sea following court of appeal shipping case? Available at: www.law.ox.ac.uk/business-law-blog/blog/2016/10/implied-good-faith-lost-sea-following-court-appeal-shipping-case (accessed: 30.01.2021). 
Waddams, Stephen. 2017. Good faith, good conscience, and the taking of unfair advantage. Defences in contract, eds Dyson, Andrew, Goudkamp, James, Wilmot-Smith, Frederick: 63-86. Oxford, Portland, Hart Publ.

Watts, Peter. 2014. Taxonomy in private law - furor in text and subject. New Zealand Law Review: 107-144.

Whittaker, Simon. 2012. Introduction. Chitty on Contracts, ed. by Beale, Hugh. $31^{\text {st }}$ ed. Vol. 1. General Principles: 3-118. London, Sweet \& Maxwell Ltd.

Willmott, Lindy, Christensen, Sharon, Butler, Des, Dixon, Bill. 2018. Contract law. Oxford, Oxford University Press.

Zimmermann, Reinhard, Whittaker, Simon. 2008. Good faith in European contract law. Cambridge, Cambridge University Press.

Received: December 23, 2020

Accepted: January 12, 2021

\title{
Принцип добросовестности и честного ведения дел в английском договорном праве
}

\author{
Ян Хальберда
}

Для цитирования: Halberda J. The principle of good faith and fair dealing in English contract law // Правоведение. 2020. Т. 64, № 3. С. 312-325. https://doi.org/10.21638/spbu25.2020.301

С учетом того, что континентальная цивилистическая доктрина оперирует концепцией добросовестности либо в субъективном смысле данного понятия (честность на самом деле), либо в объективном (добросовестность и честное ведение дел как стандарт оценки поведения), настоящая статья фокусируется на последнем значении рассматриваемого понятия. Традиционная точка зрения в Англии и Уэльсе отвергает признание общего принципа добросовестности и справедливости в английском праве. Английские суды восприняли подход, основанный на половинчатых решениях этой проблемы (как показывают прецеденты Interfoto Picture Library (1987) и Walford v. Miles (1992)). Между тем этот принцип, наряду с концепцией свободы договора, является одним из наиболее важных принципов континентальной традиции гражданского права (см. ст. 1104 Гражданского кодекса Франции, § 157, 242 Германского гражданского уложения, ст. 2 (1) Гражданского уложения Швейцарии, ст. 6:2 Гражданского кодекса Нидерландов, ст. 5 Гражданского кодекса Польши, ст. 2 (1) Общего европейского права купли-продажи (Common European Sales Law, CESL), ст. 1:201 Принципов европейского контрактного права (Principles of European Contract Law, PECL), ст. III-1:103 Модельных правил европейского частного права (Draft Common Frame of Reference DCFR). В статье анализируется недавнее английское прецедентное право (в частности, прецедент Yam Seng (2013)), которое, как представляется, признало принцип добросовестности и честного ведения дел, отвергая при этом вышеупомянутую традиционную точку зрения. Использован сравнительно-правовой подход, поскольку в статье имеются ссылки на американское право и на право стран Британского Содружества, а также на законодательство отдельных европейских государств. Главный тезис автора состоит в том, что представление о враждебном отношении английского права к понятию добросовестности в объективном смысле является поверхностным. Можно ожидать, что в ближайшем будущем суды Англии и Уэльса пойдут по пути, намеченному судами США (§ 205 (Второго) Свода договорного права (1981)), Австралии (прецедент Renard Constructions (1992)) и Канады (прецедент Bhasin v. Hrynew (2014)) и наконец признают добросовестность в качестве основополагающего принципа.

Ключевые слова: частное право, английское право, общее право, добросовестность, злоупотребление правом.

Статья поступила в редакцию 23 декабря 2020 г. Рекомендована в печать 12 января 2021 г.

Хальберда Ян - PhD, доц., Ягеллонский университет, Польша, 31-007, Краков, ул. Голебия, 9; jan.halberda@uj.edu.pl 